\title{
EC may propose universal BST ban
}

In April, Directorate General XXIV (for consumer policy and consumer health protection) of the European Commission (Brussels) suggested that the use of bovine somatotrophin (BST) should be banned in Europe. In suggesting the ban, DG XXIV cites evidence from reports published in March by two of its committees. According to the Scientific Committee on Animal Health and Animal Welfare, the use of BST for milk production increases mastitis, foot and leg problems, and other production-related diseases. It concludes, "avoidable actions which result in poor welfare, such as BST usage, should not be permitted." A second report, by the Scientific Committee on Veterinary Measures, entitled "Public Health Aspects of the Use of Bovine Somatotrophin," raises concerns that BST may affect human health. The reports states, "It is estimated that $3-10 \%$ of the human population is allergic to penicillin and other $\beta$-lactam antibiotics, which constitute the most common therapeutic treatment for clinical mastitis." According to an anonymous speaker within the commission, "DG XXIV will now suggest a ban on imports [of any produce farmed using BST]." Monsanto (St Louis, MO), the manufacturer of BST, would not speculate about a ban. A company spokesperson said, "Authorities have looked at the safety of dairy products that come from [BST] supplemented cows and have confirmed that those products are safe."

\section{NSAID war escalates}

Searle's (Skokie, IL) COX-2 inhibitor, Celebrex, a nonsteroidal anti-inflammatory drug (NSAID), was linked to 10 deaths and 11 gastrointestinal hemorrhages in the three months following approval in January for use in rheumatoid arthritis. Within a week of filing a quarterly adverse-effects report with the FDA in April, Searle saw sales of Celebrex, which had already racked up 2.5 million prescriptions, plunge sharply. Around the same time, an FDA advisory committee recommended approval of Merck's (Whitehouse Station, NJ) COX-2 inhibitor, Vioxx, for osteoarthritis and acute pain, escalating an NSAID war between Searle and Merck. "A cause-effect connection between the deaths and hemorrhages cannot be confirmed," says Peter Isakson, executive director of COX-2 development at Searle. And with so many prescriptions of Celebrex issued, analysts say they would have expected more adverse-effect reports. Meanwhile, Merck's application for wider indications has led analysts to speculate that, despite its three-month handicap, sales of Vioxx could overtake those of Celebrex.

\section{Sequenom cashes chips}

In one of the biggest private financings in biotechnology so far this year, Sequenom (San Diego, CA) raised $\$ 37$ million in mid-April to support the launch of its DNA analysis products later this year. Its first commercial offering will be a mass spectrometer accommodating

Business and Regulatory News Briefs written by Alka Agrawal, Vicki Brower, Jeffrey Fox, John Hodgson, Adam Michael, Bette Phimister, and Asako Saegusa. its low-density DNA chips, together with robotic, readout, and informatics peripherals. The share price in this offering, $\$ 6.50$, represents an increase of over $100 \%$ on the previous finance round, which took place in January 1998. This gives Sequenom a valuation "north of $\$ 100$ million," according to Toni Schuh, Sequenom's executive vice president for business development. He says that new money means the company is now ready to launch its system into the R\&D market for genotyping (gene discovery and pharmacogenomics in essence) and to prepare to commercialize in the routine DNA diagnostic area. Schuh believes that within two or three years there will be substantial demand for for genotyping. Some of that will be accelerated by the burst of activity in human SNP mapping (see p. 526).

\section{Codex stalls again on labels}

During the annual meeting of the Committee on Food Labeling of the United Nations Codex Alimentarius Commission (Rome)-which sets standards for the world trade of food products-held this spring in Ottawa, Canada, the US and Argentine delegations blocked efforts to develop a consensus position on whether or how to label foods derived from genetically engineered organisms. The reason for the impasse is that the US and Argentine delegations are calling for "voluntary" labeling, while most other delegates, including representatives of European Union states, Canada, Australia, and Japan, favor some form of mandatory labeling. The difference of opinion is that the US and Argentina argue that genetic modification is not a significant change, and therefore does not require labeling. In response to the current impasse, the committee established a 30 member working group to develop definitions and alternate proposals for such labeling, to be considered at the next meeting, scheduled for May 2000. In the meantime, the US will not be labeling produce from genetically modified sources, and other countries can adopt their own rules. Although the US delegates recommended that the Codex committee direct attention to develop principles for avoiding the "misleading labeling" of foods, including claims of health benefits that are "not based on sound science," committee members deferred discussion of that proposal as "new business."

\section{Jinxed award goes to troubled winner}

Pascal Brandys, the CEO of Genset (Paris), received the Outstanding Service to Biotechnology Award from the European Life Sciences Partnering Foundation at its annual Amsterdam conference in April. Brandys received the award just weeks after his company's stock price received downward pressure on rumors that Genset's SNP mapping program was going to be undermined by a consortium of pharmaceutical firms planning to undertake the research themselves (see p. 526). Previous recipients of the prize, formerly known as the European Entrepreneur award, are Louis Nisbet, the former CEO of Xenova (London), Glen Travers, the former CEO of Cortecs (Cambridge, UK), Keith McCullagh, the former CEO of British Biotech (Oxford, UK), and Jürgen

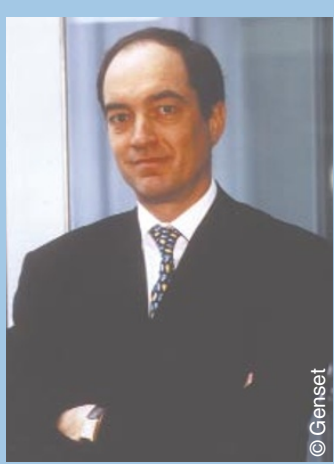
Pascal Brandys Ruttgers, the former German science minister. Because of its association with imminent demise, the prize is frequently dubbed the poison chalice award within the industry. One observer at the prize giving in Amsterdam summed up his feelings for Brandys by quoting a line from a Douglas Adams novel. Moments before the earth is destroyed, the Dolphins, who have arranged to hitchhike off the planet, turn to the humans facing annihilation and say, "So long, and thanks for all the fish.' 